УДК 929 Михаиловић, Константин https://doi.org/10.18485/msc50.2019.1.ch26

Ђорђе Живановић

\title{
КОНСТАНТИН МИХАИЛОВИЋ ИЗ ОСТРОВИЦЕ, СРЕДњЕВЕКОВНИ РАТНИК, СЕОБАР И КЊИЖЕВНИК
}

Константин Михаиловић из Островице прави је представник нашег средњевековног сеобара, потукача, он је све то био по вољи виших сила којима није могао управљати. Кад би се начинила мапа његових сеоба, био би то веома велики део средње и можда западне Европе, донекле и југозападне Азије, нама ближе. А никако се по његовој младости није могло наслућивати да ће толика пространства превалити и опет на крају, свеж и чио, написати дело које је једно од веома запажених у времену око краја средњега века и почетка новога.

Константин Михаиловић своје сеобе почиње од свога Новога Брда. Један податак који спомиње у своме делу каже нам да је 1453. године деспот Ђурађ Бранковић морао по обавези да пошаље султану 1500 војника за неки његов поход, па се у томе одреду налази и Константин. Командовао је овим одредом Јакша Брежичић, праотац каснијих славних Јакшића, који су после постали веома уважени у Угарској. Да одмах споменемо, наведену годину знамо са друге стране, јер Константин у своме делу године не бележи. Из овог једног податка закључујемо најпре да је Константин те године, када је заузет Цариград, био војник, морао је имати бар осамнаест година, а то би значило да је рођен не после 1435. Још нешто нам говори овај један податак. Опет са друге стране сазнајемо да је султан тражио од српског деспота особито оне људе који су били вични рушењу јаких зидова. Из тога би се могло закључити да је наш Константин био у Новоме Брду рудар, минер у руднику. Је ли имао завршене и какве школе, не би се могло рећи, али сва је прилика да у Србији није много учио, баш ако је и умео да чита. Причајући о овоме своме првом ратовању, Константин каже да им је речено да ће ићи на Караманију, а ови људи су доведени пред Цариград, тада престоницу Византије и употребљени за заузеће престонице источног хришћанства. Ово је изазвало поколебаност међу овим Србима. Зато одлучише да се врате натраг, али 
им је одмах скренута пажња да морају слушати и да ће бити уништени ако остану при својој одлуци. И они се покорише. Од тога часа почиње у Константину велика унутрашња борба, он је од почетка морао да чини што му није било драго. И како је тада почело, тако је трајало кроз читав његов живот скоро, да се дуга унутрашња борба у души овог ситног човека ипак заврши одлуком да учини нешто значајно, велико, да напише књижевно дело о свим тим лутањима и колебањима и да то остави потомству.

Константин се из Цариграда вратио у своје Ново Брдо. Али кратко ту остаје. После две године султан крете с војском на север, па између осталих градова опседе и заузе и Ново Брдо. То је био најтежи доживљај у Константиновом животу. Са много потресних детаља описује он све што се тада збивало с овим знаменитим градом у Србији. Султан одваја младиће и дечаке, девојке и младе жене, а онда остало становништво. Прве под јаком стражом одводи да од њих начини јаничаре, младе жене и девојке дарује војницима, највиђеније људе из града поубија, а остало становништво враћа назад у град. Свакако да Константинови родитељи, уколико их је имао, нису спадали међу виђене грађане, јер би тада били убијени, а онда би то Константин свакако споменуо. Он то не спомиње.

То је била велика прекретница у Константинову животу, од тада почињу велика лутања и авантуре, непрестано ратовање, и то у разним крајевима југоисточнога простора. И велике унутрашње борбе. Прва је била већ онда када једна група гоњених српских младића одлучи у близини града Самокова у Бугарској да бежи. Али убрзо бивају похватани, жестоко кажњени и поново враћени у вођену гомилу. Међу овим младићима је и Константин. Први пут ће тада рећи за себе и своје другове: „Чудо је како су у нама душу оставили”. Али је ипак то преживео, да се више не усуђује да бежи. А и чему, морао се питати много пута.

Већ од следеће године (1456) Константин је турски војник и учествује при нападу на Београд. Свакако је припадао тада неком пратећем одреду, свакако комори, јер при крају овога напада он ће рећи да су гледали, свакако с неке висине из позадине, како јаничари нападају Угре, а и ови их гоне и секу. Већ годину дана касније видећемо и њега као јаничара. Свакако је морао проћи и кроз неку војну школску припрему за то. Тако је Константин постао елитни војник султанов - јаничар. Он ће више пута рећи да је јаничар, мада су понеки сумњали да је могао у том узрасту постати то. Чак је постао и јаничарски официр.

Константин је као јаничар ишао из похода у поход славнога Мехмеда Освајача. О свему томе он пише у своме делу, па ће оно што пише бити извор првокласних података о тим походима. Јер он је увек у непо- 
средној близини султановој па је знао много више и боље, и потпуније, него какав обичан турски војник. Он пише своја сећања о збивањима у то време као очевидац, па зато ти редови у његову делу имају значај изванредних историјских извора. А у његову делу наћи ће одраза и велики број појединости које су проистицале из његових сећања, из онога што је носио у себи као приче о прошлости српскога народа онако како су до њега допирале. И таквих појединости биће у његову делу веома много.

Осврнимо се само на неке појединости које говоре о збивањима у његовој непосредној близини, или таквима у којима је и сам учествовао. Ево само једнога таквога примера.

Причајући како јаничари освајају утврђене градове, Константин је то тако живо описао да би заиста тешко било претпоставити да није и он лично више пута доживео страхоте таквих јуриша на градске зидине. Он прича најпре како се врше припреме за један такав јуриш. Тада се, вели он, ватром из топова најпре начини на неком месту пролом, па се онда јаничари ноћу приближе томе месту и чекају свануће. А кад сване, најпре топови поново заспу то место учестаном паљбом. Одмах после тога јаничари јуре с лествицама на зидове, јер бранилаца тада не може бити на њима. Али чим браниоци опазе јаничаре, окрећу се натраг и почињу да туку са свих страна. Јаничари се пужу уз лествице, гурајући један другога напред. За све то време с бокова лете густо стреле и пуцају пушке, диже се хука од бубњева и људске вике. Такав напад може да траје највише један сат, или можда два. Ако се не успе при првом налету, све мора да ослаби, правога напада не може бити, јер тада већ многи бивају поубијани, многи израњављени, а остали су преморени од огромног напора.

Кад се прочита овакво место у Константинову тексту, осећа се по начину причања да то није нека општа слика, него је исечак из личног доживљаја. Константин је морао и сам више пута доживети овакав напад чим га је могао овако пластично да представи. А таквих места је пуно у његову делу.

Врло је занимљиво да Константин никако не спомиње да је примио ислам, јер себе назива више пута хришћанином, бар посредно. Једном ће чак изриком написати да је хришћанин. И то онда када сретне изасланике босанскога краља Стевана Томашевића и жели да их увери како примирје које им је султан тобож пружио није истинито и да ће ускоро султанска војска да крене на Босну. Они му не верују, а он ће рећи да му морају веровати јер је и он хришћанин као и они. Онда је занимљива и појединост да Константин постаје јаничар као већ одрастао човек, а обично се тврди да су у јаничаре узимана деца. Таквих загонетака биће још у Константинову делу. А њему се мора веровати, он није био толико 
учен да би могао извртати своју истину, нити свестан да ће то некада можда изгледати као загонетка.

Константин ратује тако без престанка. Најпре бива у походу на Пелопонез. Споменуће тада и говориће доста о освајању Патраса и Мистре, па ће истаћи и тешку опсаду Коринта, после које је дошло до напуштања ове тврђаве. И о другим борбама говори Константин, каткад са доста карактеристичних појединости, јер је био у свима тим борбама веома ангажован ратник. Говориће о освајању кавкаских земаља, особито Грузије, или бар борби у њима. Видеће многе градове и земље. Био је и у Азији, зашао у Персију, па ће споменути и Вавилон, који је видео у даљини при проласку турске војске. Имао је тај град у сећању из давних причања. Био је и на Еуфрату, па ће за њега рећи да се улива у Црно море. Значи да није баш добро знао географију. - После тога Константин ратује у Влашкој против кнеза Влада и ту је доживео велика искушења, јер је борба била врло тешка и пуна изненађења. Особито је подробно описао борбе при преласку преко Дунава, када учествује у првом одреду јаничарском који се пребацио преко реке да успостави мостобран. Врло ће подробно описати тешке борбе са жестоким ратницима влашкога војводе. Како са друге стране знамо, то је било 1462.

После тога је дошла за Константина веома тешка година: 1463, када је заузета Босна. Има пуно болног савлађивања кад се Константин среће у Једрену с посланицима краља Стевана Томашевића, који су били задовољни што су закључили са султаном примирје, а Константин им саопштава да они немају примирје, јер ће турска војска кренути одмах за њима на Босну да је освоји. Зна Константин многе појединости о томе нападу на Босну и како је босански краљ гоњен и најзад ухваћен и погубљен. Константин ове појединости спомиње са пуно бола и саосећања што пропада још једна српска земља. После заузимања Босне султан се повлачи у Турску, а у Босни оставља само посаде у већим градовима. Тада је Константин остао са четрдест јаничара као заповедник тврђаве Звечај на Врбасу. Овако остављену Босну нападе крајем исте године краљ Матија Корвин из Угарске, опљачка је и заузе само на кратко. Константин се жестоко брани са својом малом посадом, и на крају буде присиљен да прекине борбу, кад слаби зидови његове тврђаве нису више могли да одолевају нападима. Једна Константинова мисао је занимљива при опису овога отпора: он каже како је хвалио Бога што је тако после часне, значи праве борбе, доспео опет међу хришћане. Те његове речи су веома карактеристичне за његов морал: он је свестан да се морао борити до крајњих могућности за султана коме је био заклет, и да је положио оружје тек кад више није било никаквих даљих изгледа за одбрану. Морамо ипак 
истаћи да му је касније искуство показало да ти хришћани нису никако питоми према заробљеницима, па ма који они били. То би се могло закључити по томе што Константин увек има речи прекора кад спомиње Угре и особито Матију и његова оца Јанка Хуњадија, које су често славили наши народни певачи. Зато је свакако био срећан кад се ускоро ослободио ове „слободе” и пребегао - тако се може претпоставити - из Угарске у Чешку. Ту је био међу Словенима, и то Чесима Јиржија Пођебрадског, протестанта и народног изабраног краља, који је водио веома велику пропаганду за борбу против Турака, а ипак је био анатемисан од папе. Константин грди Матију што не ратује против Турака, него се окренуо против хришћана, Чеха, јер је овај доиста напао Чешку 1468, па је вероватно тада Константин прешао из Чешке у Пољску, у којој је тада владао исто тако снажан владалац Казимир Јагјелонац, којега папе нису волеле због самовоље његове и такође га проклеле, а био је одани пријатељ чешкога краља Пођебрадског. Ни он није волео Матију Корвина. У земљи тога слободоумнога краља нашао је уточиште Константин Михаиловић. Изгледа да је у њој и завршио свој живот, јер у два маха у делу спомиње пољскога краља Јана Олбрахта, који је наследио оца Казимира и владао од 1492-1501. За владе овога пољскога краља Константин пише своје дело, које је имало да буде подстрек за организовање и борбу против Турака, који су већ били дошли на домак јужних граница Пољске.

Најзад, кад говоримо о Константинову животу, морамо се дотаћи и једног податка који налазимо у уводу најстаријег чешког текста, који је уопште најстарији сачуван писани текст Константинова дела, јер је из прве половине XVI века, и биће да је превод с пољског. Ту се за Константина каже како је узет у јаничаре, како је био на двору султана Мехмеда познат по знању турскога језика, да је био ћехаја звечајски, „а на двору краља францускога опет називан је Карел”. Из овога податка, који је дао преписивач Константинова дела, а вероватно и познавао лично Константина, чим је могао да о њему да̂ све ове податке, може се закључити да је Константин био и у Француској. То не би било немогућно, јер су током XV века многе делегације одлазиле у Француску да наговоре њихове краљеве да се придруже општем савезу за борбу против Турака. У томе савезу учествовали су и чешки краљ Јиржи Пођебрадски, и пољски краљ Казимир Јагјелонац, а и папе су тај савез потпомагале и подстицале. Ако би се ова претпоставка прихватила, Француска би била најудаљенија земља у Константиновим путовањима по европским земљама.

Тако би изгледао само у најкраћим цртама живот овог српског сеобара, који је толико путовао, толико пута био присиљаван да погиње главу и да слуша различите господаре, да најзад напише дело које је има- 
ло да буде приказивање једне страшне војске која је претила Европи, а није било силе која би је могла зауставити у надирању на север. Његово дело написано је између 1497. и 1501. И оно је имало авантуристичку судбину. Нема сачуваног оригиналног рукописа, али зато има рукописних преписа или превода, јер су они на чешком и пољском језику, а не зна се све досад који су текстови преписи а који преводи, што значи да не знамо сигурно на којем је језику Константин у ствари писао, на чешком или пољском, мада ипак претеже мишљење да је писао на пољском. Онда постоје два веома стара чешка штампана издања, једно из 1565. а друго из 1581. Та су издања према једном чешком рукопису у којем је било више преписивачких проширивања. Сви рукописи и два стара штампана издања сведоче о томе да је дело током времена, све до XVIII века, било веома популарно, јер је турска опасност претила и Пољској и Европи све до тих времена. Дело се преписивало и преводило. Према првом чешком издању и код нас је ово дело преведено 1865. године. Ваља рећи да се текстови доста разликују међу собом, у многима од њих има доста интервенција или преписивача или преводилаца, у многима има и додаваних читавих одељака из других сличних дела. Па је такав био и штампан чешки текст из 1565, с којег је начињен и први српски превод. Ту је чак и Константиново име Михаило Константиновић, па је тако ушао овај писац и у богату нашу старију историјску литературу. Тако је и ово веома популарно дело било те среће да се различито преносило, и оно је било, као и његов писац, велики луталица, сеобар.

Ваља споменути још једну појединост. Константиново дело називамо обично Јаничарове успомене или турска хроника. Тако се најчешће ово дело назива од пољскога издања Јана Лосја из 1912. У оригиналу тога назива нема, него се одмах почиње: „Почиње летописање о турском питању..." Иначе, Константиново дело није ни турска хроника у правом смислу речи, а нису ни мемоари, јер он та два садржаја уплиће вешто у своје дело како му је кад потребно: оно има много историјских елемената, има доста историје Турске и Србије, а посебно се пише о турском наоружању и начину ратовања. То је Константину било најважније, ипак. Али је и појединости из српске историје, наравно традиционалне, представио каткад са много тананости и лепога стила. То је било оно што је носио у себи као одјек народног причања. Ваља особито споменути његов опис косовскога боја, боље рећи појединости о погубљењу кнеза Лазара, такав је да га нема нигде другде у литератури. То је потресна слика, какву нећемо наћи на другом месту. Ваља рећи да је он пре свих споменуо Муратовог убицу пуним именом и презименом, и то једном га је назвао Милош Кобила, а други пут Кобилић. Он у тај опис уноси и пуно 
поезије. Мислимо ту особито на тренутак када војвода Крајмир моли да прихвати кнежеву главу на свој скут, па да и његова падне крај кнежеве, јер се тако заветовао. То је само једна појединост. А има их много више у самоме причању.

Дело Константина Михаиловића представља крупно уметничко достигнуће особито на оним местима када прича своје доживљаје, када говори о ономе што се њему догодило. Ту је понекад његово причање натопљено топлином и искреним уживљавањем у збивање. Морамо подсетити на потресну причу о младим Константиновим друговима који су се заверили да убију султана када су били на стражи крај његове ложнице. Откривени су, Константин није био међу њима, и вргнути на најстрашније муке. Свака је појединост нађена ту са пуно осећања за снажно уметничко деловање. Константин ту прича свој лични доживљај. Све до последњег тренутка када другови ноћу кришом сахрањују уморене другове и то крај пустог манастира „Не види сунца”. Није чудо што је Стеван Сремац у приповеци Заборављени Обилићи унео све Константинове реченице у свој текст, означивши их нарочитим штампарским слогом, као да је хтео рећи: „Боље се то не може написати”. Такав ће бити Константинов опис освајања Цариграда, са пуно појединости, свакако истинитих, увек захваћених из живота непосредно. Или како је описао турски поход на Трапезунт. Па ратовање у Влашкој, такође врло тешко за њега и оне њему најближе. Ту се људски живот граничио с крајњим опасностима и увек висио о концу. Најзад последњи турски поход у којем он учествује био је на Босну, који Константин доживљава са веома великом унутрашњом борбом.

Константиново писање краси вештина изналажења карактеристичних појединости, каткада сјајних поређења. Његов начин писања је сасвим друкчији него што је у наших писаца тога времена, или мало ранијих. Код нас ће писци овога времена, можда баш због своје учености, као што су Константин Филозоф, Григорије Цамблак, Димитрије Кантакузин и други писати средњевековним стилом наше црквене литературе. У томе се световњаци нису ниуколико разликовали од црквених лица. По њиховим схватањима књиге су се само тако могле писати. Код Константина Михаиловића нема ни трага таквога писања. Он је скроз световњак новога кова, сав земаљски човек, па ће зато и његови погледи и његов начин писања одговарати сасвим таквоме човеку. Ово подвлачимо и зато да потврдимо своју претпоставку да Константин за свога боравка у Србији, за своје младости, није ништа или скоро ништа учио, можда чак није био ни писмен. Да је Константин већ у Србији стекао какво школско образовање, како би хтели да докажу неки научници који 
су о њему писали (Ћирлић, Н. Радојчић), он би свакако писао као његови савременици школовани у тадашњој Србији, или бар приближно као они. А Константин је по начину писања бескрајно далеко од њих, нигде једне додирне тачке између њега и њих. Његови погледи далеки су од средњега века, он је нови хуманиста, претеча а можда и зачетник ренесансних погледа како у пољској тако и у нашој књижевности тога времена. Додуше, његовога дела као да није било на српском за његова живота, али ми о њему говоримо као о своме човеку, јер он делом својим припада нама.

Константин Михаиловић је по писању своме велики уметник. Навешћемо само једно место да се прикаже његово танано запажање појединости из живота. То је место из XXXI главе, где се говори како се турска војска пробијала кроз планинске кланце ка Трапезунту. Опис је богат појединостима, зауставимо се само на завршном моменту. У блатњавом кланцу једна камила са сандуцима пуним дуката пада и просипају се дукати. Јаничари исуканих сабаља заустављају караван док не стигне руковалац благајном. Кад султан чује зашто се караван зауставио, наређује да војници покупе и разделе златнике да би се пут ослободио. И Константин завршава ову причу: „Добро је било онима који су били близу, јер су неки доста ћарили. И ја сам се при томе задесио, али каснио: већ су сви златници били где је требало да буду, само је црна земља остала, јер ко је могао, скупљао је с травом и с блатом, отимајући један другоме, као што обично бива". Добричина Константин није хитао и зато је остао празних шака, осмехујући се свакако оном што је видео и чудећи се у себи.

Константин никако није сметао с ума зашто у ствари пише. Зато ће у више глава описати уређење турскога двора и организацију турске војске при великим нападима. Тако ће испричати и појединост како је султан покушавао да увери некога Грка да је турска вера боља од хришћанске, али му тај разговор није пружио утеху. И Константин ће после овога рећи: „Зато знајте да је турски цар веома несигуран, а Турци се веома боје да се хришћански свет не побуни и не навали на њихову земљу. Јер кад би то видели хришћани робови, који су под њим у ропству, сви би од њих одступили и хришћанима се приклонили. Ја сам много пута од њих слушао да се тога веома боје, те молимо Господа да то да”. Али хвали турску ратничку вештину. Зато ће рећи да је лош обичај код европских ратника да носе тешке и гломазне оклопе, јер ако неко сиђе или падне с коња, он је пропао, не може се сам више попети. А Турци се боре вештином.

Још једно место морамо навести из главе XLVII. Ту Константин говори о турском размножавању, па је начинио лепо и песничко по- 
ређење турског размножавања с морем, које никад не надолази нити се смањује. „А никад није мирно, него се на различитим местима узбуркава, љуљајући се овамо и онамо.” Па даље. „И Турци су налик на то: никада нису у миру, увек воде борбу из године у годину од једних земаља до других. Ако негде начине примирје, то је због њихове користи, а у другим покрајинама све зло изводе и чине, људе отимају, заробљавају, а што не може ходати - убијају". То је Константину оправдање да се обрати онима који би морали организовати отпор против ове силе. То су угарски краљ Владислав и пољски краљ Олбрахт, два брата рођена. Они би морали да организују рат против Турака. И на крају ће рећи: „А за то нема другог правилнијег пута него братска слога и јединство и љубав свих хришћана, да би од поганичке руке били ослобођени". Онда замера ранијем краљу угарском Матији што је водио рат против Чеха, а није ратовао против Турака, на то су га наговорили папа Павле II и аустријски цар Фридрих, проглашавајући Чехе за јеретике. И тако се развија борба међу хришћанима, место да се слажу и да се боре против Турака. Последња реченица у овом низу као да је утеха: „А успомена на покојног краља Матију прошла је као звук звона”.

Као што се из последњих навода види, мисионарска је била, европска улога Константина Михаиловића када је писао своје дело.

\section{ГЛАВНА ЛИТЕРАТУРА}

Pamiętniki Janczara czyli Kronika Turecka. Kraków, 1912.

Jan Loš, Pamiętniki Janczara czyli kronika turecka, Kraków, 1912.

Михаиловић Константин, Јаничарове успомене или турска хроника. (Оригиналан текст и напоредни српски превод Ђ. Живановића), Споменик САН бр. 107. Београд, 1959.

Михаиловић Константин, Јаничарове успомене или турска хроника (Покушај реконструкције основног текста и превод Ђ. Живановића), Београд, 1966', 1986². (Обиман увод и коментари).

Danti Angiolo, Ani janczar, ani autor Kroniki Tureckiej, Pamiętnik Słowiański, Warszawa, 1969, XXXVIII, стр. 101.

Живановић Ђорђе, Константин Михаиловић из Островище, Зборник МС за књижевност и језик, Нови Сад, 1976, XXIV, стр. 33-59. 